\title{
6. Unfair competition: exploring state-funded low-fee private schools' logics of action in Buenos Aires
}

\section{Mauro C. Moschetti}

\section{INTRODUCTION}

The premise that the private sector can provide quality education and increase educational opportunities for disadvantaged groups has been increasingly promoted, especially with the rise of different forms of public-private partnerships (PPPs), such as those involving charter schools, vouchers, and supply-side subsidies for private schools (Robertson et al., 2012). However, empirical evaluation of educational PPPs is still scarce, markedly inconclusive, and often focused on the overall measurement of school segregation and learning outcomes. ${ }^{1}$ Moreover, research has been mostly dominated by quantitative approaches and focused especially on charter and demand-side financing schemes - considered generically - thus leaving relevant underlying social and contextual mechanisms unspecified that would otherwise help interpret contradictory results in different contexts (Heyneman and Lee, 2016; Verger and Zancajo, 2015).

In comparison, fewer studies have explored how schools actually operate under different specific PPP schemes in socially embedded, unevenly regulated education environments (for exceptions see Jabbar, 2015; Jennings, 2010; Van Zanten, 2009; Verger, Bonal and

1 For an updated review on PPPs in the global South see Languille (2016); for a review of empirical research on market policies in education see Waslander, Pater and Van Der Weide (2010). 
Zancajo, 2016). In particular, PPPs involving supply-side subsidies for private schools - that is, funding that goes to the suppliers without a direct link to enrollment - have remained largely underexplored, despite their historical presence and growing expansion both in developed and developing countries.

Focusing on the case of the City of Buenos Aires, Argentina, this chapter explores whether state-funded low-fee private primary schools (S-LFPSs) supplement - as intended by the policy framework - or rather compete with tuition-free state schools in some of the poorest neighbourhoods of the city. In particular, we explore how S-LFPSs' principals and staff perceive and depict the role they play as 'public' education ${ }^{2}$ providers in their local educational spaces, and attempt to identify and contrast some of the most frequent logics of action they deploy to attract enrollment with those perceived roles. In doing so, we address the equity implications of these dynamics - whether they increase educational opportunities for students in economically disadvantaged areas or not - and problematize some aspects of the normative framework established by the subsidy policy vis-à-vis its policy goals highlighting its gaps, ambiguities, and enforcement shortcomings.

\section{SUPPLY-SIDE SUBSIDIES FOR PRIVATE SCHOOLS AND THE CASE OF THE CITY OF BUENOS AIRES}

The granting of supply-side subsidies for private schools is one of the least-researched forms of PPPs. While many countries have historically resorted to this modality - a 'historical form of PPP in education' (Verger, Fontdevila and Zancajo, 2016), more recently their dissemination has been on the rise in both developing countries - with the fundamental aim of expanding access to schooling for low-income students in a cost-efficient manner (Heyneman and Stern, 2014), and in developed countries - especially to increase

2 The 2006 National Education Law (No. 26.206) and its 1993 predecessor (Federal Education Law No. 24.195) refer to all types of schools as 'public'. So, private schools, be that subsidized or independent, are named 'privately-managed public schools', and accordingly, governments schools are referred to as 'statemanaged public schools'. Some argue that this 'language game' has had important consequences for legitimating the allocation of state subsidies for private schools (Feldfeber and Gluz, 2011; Gamallo, 2015; Vior and Rodríguez, 2012). 
school choice options (Bosetti, 2004; Vandenberghe, 1999; Villarroya, 2002).

Schematically, proponents of supply-side subsidies suggest that governments can provide funding for private schools to expand and/or diversify overall supply of education services - ideally by supplementing government provision (LaRocque, 2008; Montoya and Frugoni, 2016). Many advocates of market mechanisms in education see supply-side subsidy schemes as second best forms of PPPs (interestingly for the same reasons that some education policymakers, especially those in the centre-left, find these schemes somehow appealing). This is mainly because, unlike in other PPP arrangements, supply-side subsidies are not allocated on a direct per capita basis, but depending on a series of predefined eligibility criteria regarding private schools' characteristics (e.g., location and proximity to government schools, for-profit/not-for profit status, socio-economic context, and so on), and only indirectly in relation to enrollment (Patrinos, Barrera Osorio and Guáqueta, 2009). Private subsidized schools are thereby supposed to supplement government schools' limited capacity, whilst promoting a less intense form of competition thus minimizing unwanted segregation effects stemming from typical education market dynamics (Verger et al., 2017; Waslander, Pater and Van Der Weide, 2010). In short, while supply-side subsidies for private schools may respond to heterogeneous policy designs and objectives, the emphasis is usually placed on (1) expanding choice, (2) expanding or diversifying supply, or (3) supplementing insufficient state supply, rather than on promoting competition (Patrinos, Barrera Osorio and Guáqueta, 2009).

However, many of the assumptions and conditions that would ensure the proper functioning of these policies in theory may not be fulfilled or be absent in real life educational environments. In particular, school choice processes are often mediated by a series of structural constraints that are not addressed in the design of these policies (Ben-Porath, 2009; McGinn and Ben-Porath, 2014; Rich and Jennings, 2015). Consequently, eliminating or lowering private school fees by means of subsidies may not automatically imply that low-income families gain access. On the supply side, the existence of a subsidy policy may not be incentive enough to guarantee the expansion of private providers needed to make up for government under-provision. Furthermore, as with other PPP modalities, 
supply-side subsidy policies require strong state capabilities to ensure that private providers comply with existing education legislation and do not engage in opportunistic behaviour (Gauri and Vawda, 2004; Jennings, 2010; Linder and Rosenau, 2000; Lubienski, 2003). Also, in comparison with demand-side funding schemes, supply-side subsidies may pose an extra challenge for states in terms of accountability because of the diverse, complex and often ambiguous nature of the eligibility criteria and requirements regarding potential providers that need to be audited to decide upon subsidy allocation. In this regard, in developing countries, the lack of resources and state management capabilities may also lead to discretionary decisions being made by government officials (Mezzadra and Rivas, 2010). Finally, using supply-side subsidies instead of direct per capita funding schemes may not be enough to avoid de facto competitive practices among schools. This is especially the case in relation to 'second-order competition' practices whereby schools compete to recruit not just any type of student, but rather those who are more academically able or have a good attitude towards learning, discipline and so on (Gewirtz, Ball and Bowe, 1995; Lubienski, 2003; Van Zanten, 2009).

The existence of an extended policy of supply-side subsidies for private schools that dates back several decades makes the City of Buenos Aires a relevant case to analyze the functioning of this modality of provision operating in a real context. Currently more than 50 per cent of children attend private schools, of which 80 per cent attend state-subsidized private schools, and 20 per cent independent elite schools (DGEGP-CABA, 2016, DiNIECE, 2016). The subsidy policy dates back to 1947 . However, it was not until the beginning of the 1990s that it acquired its current shape and arguably paradoxical - purposes, that is, 'to guarantee the right to learn and, consequently, to choose school, in exercise of the freedom of education', and 'to ensure equal opportunities for all inhabitants to access education' (Decree No. 2542/91). ${ }^{3}$ The policy allows private schools to apply for different amounts of subsidies to

3 Something similar can be observed, for instance, in the Spanish constitution where the right to education and the freedom of instruction principles appear simultaneously and somewhat linked to each other (Verger, Fontdevila and Zancajo, 2016). 
pay for teachers and principals' salaries in some proportion (currently from 40 per cent to 100 per cent). Subsidies do not compensate for real estate investment, extracurricular teacher salaries, maintenance and so on, and schools are therefore allowed to charge extra - although limited - fees to meet these expenses. The normative framework is not particularly exhaustive in determining and operationalizing the criteria that define subsidy allocation, and vaguely refers to 'the socio-economic profile of the school', 'the style of teaching', 'the need for the school in its influence area' and its 'financial performance', without establishing clear eligibility indicators and metrics. Not surprisingly, some studies have argued that there is probably too much room for discretion in the process (Mezzadra and Rivas, 2010; Sigal et al., 2011).

Subsidies have enabled the emergence and consolidation of many different kinds of private schools, generally depending on the amount of subsidy they receive (and the corresponding fees they charge families). This research focuses specifically on the group of schools I pragmatically named 'state-funded low-fee private schools' (S-LFPS), that is, private schools (both for profit and not-for-profit, religious and non-religious) that receive full or almost full subsidies (between 80 per cent and 100 per cent) to pay for teachers and principals' salaries, and that are entitled to charge very low fees to families. ${ }^{4}$ S-LFPSs are located most frequently in the poorest neighbourhoods of the city - often facing a shortage of government schools (Martínez, 2012; Musa, 2013). As stated in an interview by an education ministry official: 'these schools give us a helping hand where we have excess demand issues, which in our case happens especially in the southern part of the city.' Interestingly, during the last decade, these schools have played a key role in explaining a strong trend towards privatization in the primary level among middle-low and low-income families (Gamallo, 2011; Judzik and Moschetti, 2016). Surprisingly, despite such trend, no

4 While there are many differences between these schools and what the literature usually portrays as LFPSs (see for instance Balarin, 2016; Srivastava, 2007; Walford, 2011), the 'affordable learning, poor household targeted, expansion of access, better quality and cost efficiency' narratives are equally present in the case of S-LFPS in Buenos Aires. S-LFPSs' fees usually range from 15 to 50 USD a month, that is between 3 per cent and 10 per cent of the minimum wage (AR \$ 8,080 in 2017), although it is evident that the comparison is valid only for formal workers (see Moschetti, 2015). 
new S-LFPSs were created throughout the period, but rather existing S-LFPSs have increased their enrollments by 50 per cent on average between 2005 and 2015 (DGEGP-CABA, 2016).

\section{METHODOLOGICAL AND CONCEPTUAL CONSIDERATIONS}

This chapter presents results and analysis forming part of a larger policy, school and household-level study on the S-LFPS sector in the City of Buenos Aires. The study's main purpose is to examine the extent and conditions under which S-LFPSs can supplement government provision and increase educational opportunities for students in economically disadvantaged areas. Following Srivastava and Hopwood's (2009) framework for qualitative data analysis, the study iteratively addresses three interrelated analytical levels: (1) the regulatory framework, or what the policy says and does in terms of 'rules of the game'; (2) the S-LFPSs' logics of action, or how schools operate within the regulatory framework; and (3) the parental choice rationalities in relation to S-LFPSs.

The discussion in this chapter is based on results at the S-LFPS level. I used case study methods to explore S-LFPSs' views on competition and the different logics of action they deploy regarding enrollment under the supply-side policy framework. I selected nine S-LFPSs offering primary education located in the city's poorest neighbourhoods to conduct on-site observations during a period of eight months, as well as in depth interviews with principals, owners, teachers, and legal advisors $(n=52)$. Schools were selected as a stratified purposeful sample on the basis of the type of provider following the average distribution prevailing in the S-LFPS sector. The final sample is composed of four schools belonging to nonprofit organizations (NPO), three belonging to the Catholic Church or to some Catholic religious order, and two belonging to private companies.

Drawing on previous, although limited, research on schools' responses to charter school frameworks, quasi-markets, and school competition in general, I developed a non-exhaustive typology of potential logics of action followed by schools in competitive scenarios as a preliminary checklist to identify whether S-LFPSs engaged in any and with what consequences (Figure 6.1). I defined 
'logics of action' following Ball and Maroy (2009), Maroy and Van Zanten (2009) and Van Zanten (2009) as an enlarged version of the concept of 'strategy' - which is usually narrowly associated to an instrumental rationality. In contrast, the concept of logic of action 'does not suppose that school agents are conscious of the effects of their choices or that they act on the basis of a rational-instrumental calculation of costs, means and benefits' (Van Zanten, 2009: 87). Logics of action can be 'strategic' - and most certainly are - but not exclusively, and, more importantly, they are inevitably mediated by a series of constraints - or 'mediating factors' (Jabbar, 2015) that are both external (regulatory framework, neighbourhood's and nearby schools' characteristics, schools relative position in the local hierarchy) ${ }^{5}$ and internal (perception of competition, ${ }^{6}$ enrollment level, student's characteristics, history and ethos, and so on) (Ball and Maroy, 2009).

Following Woods, Bagley and Glatter's (1998) and Jabbar's (2015) typologies, I distinguished six different general logics of actions schools might resort to under competitive pressure to attract enrollment. These are: academic, regarding changes in curriculum and efforts to improve quality; operational, affecting how resources are procured and used in order to gain efficiency and ultimately achieve economies of scale through expansion or the development of partnerships; differentiation, aiming at buffering from competition arguably generating a less intense 'monopolistic competition' (Lubienski, 2003) - by developing academic or non-academic niches, or offering extracurricular activities to gain uniqueness (Jabbar, 2015; Woods, Bagley and Glatter, 1998); promotional, developing various types of general or targeted communication actions; ${ }^{7}$

5 The relative position in the local hierarchy can be thought of as the position each school occupies in a subjective prestige hierarchy (see Maroy and Van Zanten, 2009). To assess this feature I relied mostly on data from the household analytical level.

6 The perception of competition - e.g., asking school principals whether they feel they have direct competitors and how many - contrasts other more objective but arguably less relevant measures of competition such as geographic density, market size, etc. (Levačić, 2004).

7 While many consider 'promotional activities' and 'marketing' to be synonyms (Gewirtz, Ball and Bowe, 1995; Jabbar, 2015), in this chapter we refer to promotional activities exclusively as external communication efforts (advertising). However, studies focusing on schools' marketing strategies in more dynamic and mature marketized environments than those created by supply-side subsidies, 
(re)localization, relating to schools' location decisions vis-à-vis the geographical demand patterns (Lubienski, Gulosino and Weitzel, 2009); and selection, which can happen ex ante (cream-skimming or cropping off), and/or ex post (getting rid of low-performing students $)^{8}$ (Jennings, 2010; Lacireno-Paquet et al., 2002; West, Ingram and Hind, 2006).

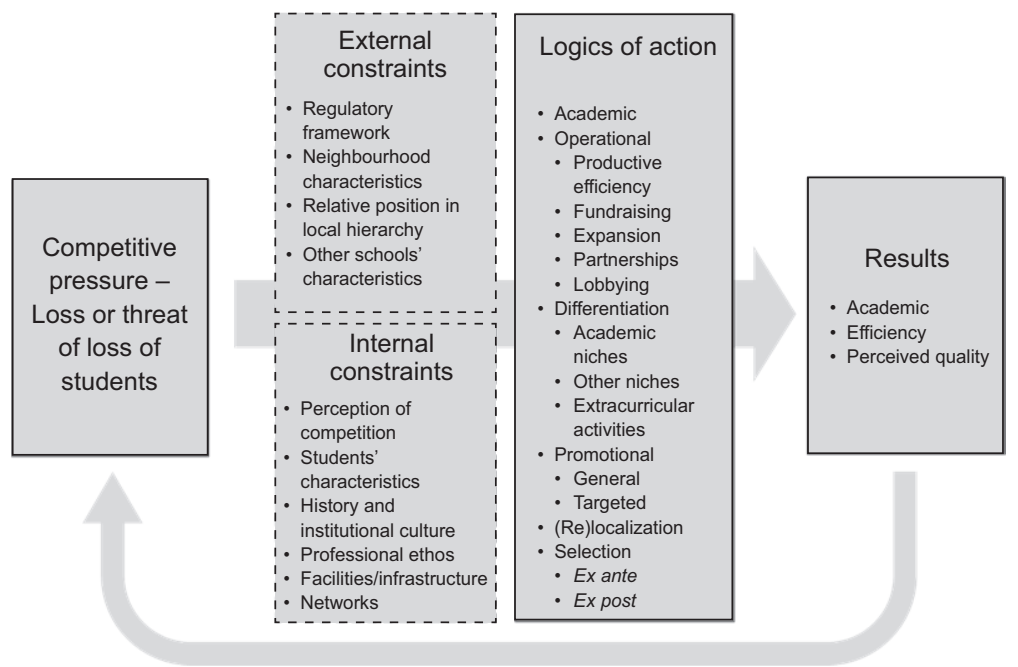

Source: Own elaboration based on Ball and Maroy (2009); Woods, Bagley and Glatter (1998); Jabbar (2015); and Van Zanten (2009).

\section{Figure 6.1 Analytical framework}

should note that marketing is a complex process in which promotional activities only occur after schools have engaged in other marketing activities such as scanning the local market (both analyzing consumer and competitor profiles), and building differentiation at the product level by means of substantive or symbolic attributes (see for instance Zancajo, 2017). It falls beyond the scope of this exploratory chapter to analyze marketing strategies from this systemic perspective.

8 Van Zanten (2009), for instance, distinguishes between 'first-order' and 'second-order' competition, that is, whether schools compete for enrollment, or rather for the 'best pupils' by means of different explicit or implicit selection practices. 
In the following sections I focus first on reviewing S-LFPS leaders' general views regarding their role as providers of 'public' education, and on whether they feel they compete or supplement government provision. Note that the 'no-competition' narrative that is, the fact that S-LFPSs are supposed to be neutral in terms of generating competitive interdependencies - embedded in most supply-side subsidy policies makes this point particularly relevant since it reveals the ways in which schools actually interpret and enact the policy on the ground. Then I describe the three most commonly observed logics of action and discuss (1) how these are mediated by certain internal and external constraints in each case, and (2) the equity implications of such logics of action in relation to the policy goals.

\section{VIEWS ON COMPETING WITH/SUPPLEMENTING GOVERNMENT SCHOOLS}

In-depth interviews showed that all school principals and owners had a very detailed knowledge of the surrounding public and private schools, especially regarding their curriculum, fees, enrollment and overall reputation. This reveals that, although informally, S-LFPSs strongly engage in market scanning practices, especially in relation to other 'producers' (Woods, Bagley and Glatter, 1998). However, both S-LFPS principals and owners were very reluctant to identify other schools as competitors. Competition appeared overall as a somewhat 'forbidden word' and principals were usually not comfortable with it, especially when referring to public schools. This does not mean that they did not experience competitive pressure:

Last year they opened a new public school a few blocks away from here; a beautiful school and, of course, no tuition fees. We were scared to death that we were going to lose enrollment. Because, of course, we have to have students to keep the school open. (NPO school principal)

Yet, the competition theme was often replaced by a narrative of cooperation and harmonic relationship in which S-LFPSs principals tried to discursively blur their differences with government schools arguing that - as charter school proponents usually emphasize (Nathan, 1996) - state-funded private schools are to be considered 
just as public as governments schools. Accordingly, they depicted their role as 'cooperating with government schools', or neutrally 'offering alternatives for families':

I wouldn't say we compete for enrollment with public schools ... We are part of the same education system. We are a private school but we are part of the same public education system, then we are public too, I think. (Private company school owner)

Families can choose whatever suits them best; they can go for public or private subsidized. All alternatives are equally valid. (NPO school principal)

These conflict-free narratives paradoxically contrast with S-LFPS principals and owners sharing a widespread negative view about public schools, especially regarding quality and teacher engagement. That sense of superiority might be behind not recognizing public schools as competitors. Most principals, especially those at NPO schools, usually experienced a somewhat moral dilemma when criticizing public schools, which they creatively solved by saying that it was not their own actions but public schools' poor performance that kept S-LFPSs' enrollments up. In a similar vein, some S-LFPS principals denied the existence of competition and accused public schools of not being open to their cooperation attempts:

It is impossible for us to build relationships with public schools. They won't talk to us. They label us as if we were stealing students from them, I don't know why, it's just crazy. (NPO school principal)

Interestingly, from the perspective of public schools, it appears that S-LFPSs 'steal' students from them. However, the nature of such competition remains unclear and is strongly mediated by the neighbourhood's schooling dynamics, and especially by the fact that these neighbourhoods have historically suffered from having not enough schools (considering both public and private) (Musa, 2013; Sigal et al., 2011). As one Catholic S-LFPS principal put it: 'Fortunately or unfortunately, there's "fish for all" in this district'. While competition dynamics are more evident when supply clearly outstrips demand and forces under-enrolled schools to close, competition can take more subtle forms and schools may compete for 
enrollment and resources but simultaneously for other less obvious forms of capital such as prestige and reputation. Prestige and reputation, as many have noted, are some of the most relied on proxies used by families in their school choice decisions; so, for schools, prestige and reputation increase desirability and may lead to success in enrollment. However, in education services production, competition for prestige is closely linked with competition for certain types of students. As noted by Van Zanten (2009: 86): 'in all service professions, the characteristics of clients strongly modify work content and occupational prestige. This triggers a "secondorder" competition between schools to get the best - usually conceived as the most academically able - students'. Arguably, public schools in the area feel threatened by the existence of S-LFPSs not because they might end up having less students which is most unlikely given the current demand-supply imbalance - but probably 'less academically able' ones.

\section{MOST COMMONLY OBSERVED LOGICS OF ACTION}

\section{Selection of Students}

Selection of students was by far the most commonly observed logic of action deployed by S-LFPS in their relationships with demand. Despite being explicitly forbidden and most infrequent in primary education internationally, selection practices were more or less openly described by eight out of nine S-LFPS principals. In two cases, even web pages contained detailed information on the admission criteria and process.

S-LFPSs engaging in selection practices had formal admission processes and usually used between two or three different selection techniques such as academic tests, screening interviews with candidates and parents, psychological tests, examination of academic records and reports (if transferring from another school), among others. Behavioural issues and academic aptitude were the key concerns and so academic and psychological tests were among the most frequently-used techniques. 
When describing their selection processes, some principals, owners and teachers 9 were more explicit in describing what they expected and what these processes included:

They must go through the interviews and they must pass the admission exams in order to be admitted; math and language. Siblings, little brothers, sisters, cousins, everybody has to take and pass these exams if they want to get a spot. If they're relatives, then it's easier because we already know the family, but they must pass the exams anyway. (NPO school teacher)

In comparison, others were more 'self-conscious' and resorted to explanations emphasizing the potential 'fit' between the school and the family. Interestingly, in religious S-LFPSs such fit was not initially linked to the family's religious beliefs:

There's a first interview with the psychopedagogue. Parents also have to bring a report from the previous school or kindergarten. What we try to do is ... not to select, but to see if the kid would fit in the group. We interview the parents too, and then there is an exam to see if the child ... It's not a qualifying exam ... it's kind of diagnostic. We don't want the kid to feel he/she's out of place. Sometimes parents understand, and sometimes they don't. (Catholic Church school principal)

There is an admission process including a small test, to know where they come from, a small interview with the family ... And sometimes, a small test with the psychopedagogue, to see if ... That is, no one is discarded for their knowledge, but we evaluate whether this is the best school for that family, whether we can help. (NPO school principal)

Only one school in the sample did not select students. The institutional decision against selection was the consequence of both internal and external constraints that made selection both unacceptable and unstrategic. In particular, the school's history and institutional culture - being originally a pre-school day care institution for disadvantaged children - and its principal's 'missionary' professional identity made its staff experience a moral rejection regarding student selection. Also, the surrounding schools - mostly, religious

\footnotetext{
9 Teachers were usually in charge of the first phases of the selection processes.
} 
S-LFPSs - were highly selective ${ }^{10}$ and thus better positioned in the local hierarchy. So, while this school was not under-enrolled initially thanks to the overcrowding and 'bad press' of public schools in the area - it served many 'repeaters' and 'rejects' coming from other S-LFPSs in order to fill all the spots.

Overall, schools gave three different types of justification for selecting students: (1) pragmatism ('We have more applicants than spots and, besides, every school does it this way'); (2) legal ('As private institutions we reserve the right of admission'); and (3) meritocracy ('We offer high-quality education and not everybody can cope with it'). Paradoxically, the normative framework forbids student selection, ${ }^{11}$ and S-LFPS' principals referred to their schools as 'public' - in line with their legal denomination - and as part of an institutional network bearing a pro-poor, pro-equity approach to education. At the same time, however, the legislation allows S-LFPSs to operate admissions on a school-based basis, whereas public school admissions are run through a centralized on-line single-blind application system. The pervasiveness of selection practices reveals these normative inconsistencies but, more importantly, a strong lack of government oversight over opportunistic behaviour.

\section{Operational Changes}

Efficient use of resources and resource development were major concerns among S-LFPSs principals and owners. Since subsidies are aimed at financing only teachers' and principals' salaries, and tuition fees are limited by the ministry, most S-LFPSs engaged in a series of practices to either make intensive use of or increase available resources.

In order to increase available resources, most S-LFPS engaged in fundraising activities to some extent. Fundraising was usually performed using the legitimating halo stemming from S-LFPSs'

10 One of these schools preferred having empty seats than recruiting certain types of students for prestige and cost-efficiency reasons. Interestingly, this was the case even in the absence of high-stakes testing accountability systems (compare with Jabbar, 2015; Lubienski, 2005).

11 Law $\mathrm{N}^{\circ} 2.681 / 08$ states that reasons for not admitting or not readmitting a student in a private institution should not be contrary to the rights recognized in the National Constitution and in the Constitution of the City of Buenos Aires. 
serving economically disadvantaged students. However, not many S-LFPSs had the capacity and/or expertise to sustainably raise funds. Some, especially among NPO schools, had quite sophisticated fundraising programmes, targeting corporations and individual donors. In these cases, recurring donations represented between 20 and 30 per cent of the schools' operating budget. Still, the majority performed less systematized fundraising activities and could not rely on these resources to cover current expenses. One-time donations were most commonly applied to the purchase of teaching materials or to building new facilities, depending on the amount.

Another way of increasing available resources consisted in offering extracurricular activities, additional subjects and services. This is because maximum fees apply basically for curricular subjects but admit great flexibility for extras. Accordingly, while additional offers helped to build differentiation, they also provided schools with the chance to bypass the maximum fees regulations and charge add-ons to basic fees. Seven out of nine schools in the sample engaged in some kind of product and price engineering.

On the other hand, expansion and increasing class sizes were the most frequent practices to gain productive efficiency. Over the last ten years every school in the sample had expanded in one way or the other. Expansion strategies ranged from building more classrooms and, when possible, expanding into kindergarten and/or secondary levels, to partnering or merging with other neighbouring schools to achieve economies of scale, especially by centralizing administrative activities. Also, seven out of nine schools had grown to having more than 45 students per classroom thus maximizing the use of both available facilities and teacher salary subsidies while collecting more individual fees.

\section{Differentiation}

Differentiation as a means of attracting enrollment operated in two different levels. First, at a 'collective level', as a means of buffering S-LFPSs against competition from government schools in general. Whether formally coordinated or not, S-LFPS seemed to work in coalition attempting to secure (potential) market share for all. This happened especially in the discursive dimension with S-LFPSs 
building and communicating an overarching set of symbolic attributes from which government schools were excluded. These discourses clearly resonated with the general highly-mediatized crisis discourses targeting public education. The 'better quality mantra' was systematically repeated by all S-LFPSs' principals, owners and teachers in their conversations with parents to mark a difference with government schools. This was reinforced by the incorporation of uniforms and a narrative of a "personalized and caring teaching style' as opposed to public schools depicted as 'chaotic and insecure environments for learning'. Moreover, S-LFPSs' not having teacher strikes was used as the most frequent selling point for parents who were also considering public schools. To a great extent - and in contradiction with the rhetoric of collaboration - S-LFPSs' public image was essentially constructed as an opposition to government schools.

Second, differentiation logics of action operated at an institutional individual level, as a means of buffering S-LFPSs against competition from other S-LFPSs and from some public schools. In these cases, differentiation was less discursive and instead materialized in better-looking facilities, extracurricular offers, and niche programmes, some being academically relevant. Four schools in the sample, for instance, developed some kind of niche programme, both academic and non-academic - according to Jabbar's (2015) distinction: bilingual, same-sex education, special educational needs and tracking. In some cases, these were said to be the key for having increased their 'trade area':

We have many students coming from very far away because of our bilingual program ... one, even two-hour bus rides. (Private company school principal)

Schools marginally engaging or not engaging in differentiation practices $(n=2)$ usually found it relatively more difficult to increase enrollment. However, they were still able to keep their classrooms full, arguably profiting from the collective differentiation logics of action and developing 'de facto niches' such as accepting repeaters and students expelled from other schools. 


\section{CONCLUSION}

Findings from this study suggest that no matter how indirectly subsidy allocation is linked to enrollment, the fact that there exists some connection - mediated by the number of teachers, for instance - is enough to create competitive pressure and, accordingly, different responses from schools. This is mainly because, as stated by Van Zanten (2009: 86), 'even in systems where school budgets are not allocated on a strict per capita basis, most other resources ... are allocated according to the number on pupils'. Moreover, when state-funded private schools are allowed to charge fees and these represent a significant portion of schools' operating budget, competition receives an extra boost. In the case of supply-side subsidy schemes, predefined eligibility criteria for subsidy allocation could create some barriers against competition - especially shaping the kind of private providers allowed to participate and favoring, for example, non-profit organizations. However, exploratory findings from this study show no clear differences between for-profit and not-for-profit S-LFPSs regarding their orientations to competition operating under the same policy framework (see similar findings in Bano, 2008).

Among the most frequent logics of action, second-order competition, as evidenced in the pervasive student selection practices, appears as incompatible with the policy goals of S-LFPSs supplementing public provision while ensuring equal opportunities. Furthermore, while differentiation logics of action lead to some curriculum diversification or the development of academically relevant programmes in some cases, most frequently differentiation was either a student selection-driven practice carrying additional costs for families, or otherwise happened at a discursive-symbolic dimension emphasizing public schooling's shortcomings. Interestingly, most competitive logics of action showed some interconnectedness in line with the incentives generated by the policy. For instance, having 45 students per classroom (thus maximizing subsidy and facility use) is arguably sustainable only by means of selecting the most academically able. Likewise, selection practices then increased demand by reinforcing S-LFPSs' image as quality schools opposing that of public schools. 
Finally, while some studies have long described the segmented (or fragmented) nature of the educational system of the City of Buenos Aires (and Argentina) (Braslavsky, 1985; Krüger, 2012; Tiramonti, 2004), this study helps identify some of the school- and policy-level mechanisms that produce such trends and that are more subtle than fee charging. In this sense, this study suggests that normative inconsistencies and the lack of state oversight play an important role in exacerbating competition's adverse effects. In particular, S-LFPSs are granted more formal and informal tools to potentially compete, as compared to public schools. This is the case of S-LFPSs having substantively more autonomy to define curriculum and hire and fire teachers (Gottau and Moschetti, 2015). Also, enrollment residential boundaries apply for public schools but, interestingly, not for S-LFPS. In addition, S-LFPSs operate admissions on a school-based basis leaving room for opportunistic behaviours - as evidenced in this study - whereas public school admissions run on a centralized on-line single-blind application system. These elements are certainly at the root of the segregation dynamics, the consequent loss of positive peer effects and the damage to social cohesion. Arguably, for S-LFPSs to actually supplement public provision much more state oversight and equal regulations for public and S-LFP schools are needed.

\section{REFERENCES}

Balarin, M. (2016). La privatización por defecto y el surgimiento de las escuelas privadas de bajo costo en el Perú. ¿Cuáles son sus consecuencias? RASE: Revista de La Asociación de Sociología de La Educación, 9(2), 181-196.

Ball, S.J. and Maroy, C. (2009). School's logics of action as mediation and compromise between internal dynamics and external constraints and pressures. Compare: A Journal of Comparative and International Education, 39(1), 99-112.

Bano, M. (2008). Non-profit education providers vis-à-vis the private sector: comparative analysis of non-governmental organizations and traditional voluntary organizations in Pakistan. Compare: A Journal of Comparative Education, 38(4), 471-482.

Ben-Porath, S.R. (2009). School choice as a bounded ideal. Journal of Philosophy of Education, 43(4), 527-544.

Bosetti, L. (2004). Determinants of school choice: understanding how parents choose elementary schools in Alberta. Journal of Education Policy, 19(4), 387-405. 
Braslavsky, C. (1985). La discriminación educativa en Argentina. Buenos Aires: FLACSO, Grupo Editor Latinoamericano.

DGEGP-CABA. (2016). Buenos Aires. Retrieved 22 May 2018 from http:// www.buenosaires.gob.ar/educacion/escuelas/gestion-privada.

DiNIECE. (2016). Anuarios Estadísticos. Buenos Aires. Retrieved 22 May 2018 from http://portales.educacion.gov.ar/diniece/2014/05/24/anuariosestadisticos/.

Feldfeber, M. and Gluz, N. (2011). Las políticas educativas en Argentina: herencias de los '90, contradicciones y tendencias de "nuevo signo." Educação \& Sociedade, 32(115), 339-356.

Gamallo, G. (2011). Mercantilización del bienestar. hogares pobres y escuelas privadas. Revista de Instituciones, Ideas Y Mercados, (55), 189-233.

Gamallo, G. (2015). La 'publificación' de las escuelas privadas en Argentina. Revista SAAP, 9(1), 43-74.

Gauri, V. and Vawda, A. (2004). Vouchers for basic education in developing economies: an accountability perspective. The World Bank Research Observer, 19(2), 259-280.

Gewirtz, S., Ball, S.J. and Bowe, R. (1995). Markets, Choice, and Equity in Education. Milton Keynes: Open University Press.

Gottau, V. and Moschetti, M. (2015). El Sistema Educativo Argentino Entre la Privatización Interna y la Privatización Abierta: Trayectorias Divergentes y Desigualdades. Cadernos de Pesquisa: Pensamento Educacional, 10(26), 182-202.

Heyneman, S.P. and Lee, B. (2016). International organizations and the future of education assistance. International Journal of Educational Development, $48,9-22$.

Heyneman, S.P. and Stern, J.M.B. (2014). Low cost private schools for the poor: what public policy is appropriate? International Journal of Educational Development, 35, 3-15.

Jabbar, H. (2015). 'Every kid is money': market-like competition and school leader strategies in New Orleans. Educational Evaluation and Policy Analysis, 37(4), 638-659.

Jennings, J.L. (2010). School choice or schools' choice?: Managing in an era of accountability. Sociology of Education, 83(3), 227-247.

Judzik, D. and Moschetti, M. (2016). ¿Una segunda fase de privatización de la matrícula escolar? Los sectores populares y la educación privada en la Ciudad de Buenos Aires. Revista de La Asociación de Sociología de La Educación, 9(2), 197-211.

Krüger, N. (2012). La segmentación educativa argentina: reflexiones desde una perspectiva micro y macro social. Páginas de Educación, 5(1), 137-156.

Lacireno-Paquet, N., Holyoke, T.T., Moser, M. and Henig, J.R. (2002). Creaming versus cropping: charter school enrollment practices in response to market incentives. Educational Evaluation and Policy Analysis, 24(2), $145-158$.

Languille, S. (2016). Public-private partnerships in education and health in the global south: a literature review. Journal of International and Comparative Social Policy (ahead-of-print), 1-24. 
LaRocque, N. (2008). Public-Private Partnerships in Basic Education: An International Review. Reading, UK: CfBT Education Trust.

Levačić, R. (2004). Competition and the performance of English secondary schools: further evidence. Education Economics, 12(2), 177-193.

Linder, S.H. and Rosenau, P. (2000). Mapping the terrain of the public-private policy partnership. In P. Rosenau (ed.), Private-Public Policy Partnerships (pp. 1-18). Cambridge, MA: MIT Press.

Lubienski, C. (2003). Innovation in education markets: theory and evidence on the impact of competition and choice in charter schools. American Educational Research Journal, 40(2), 395-443.

Lubienski, C. (2005). Public schools in marketized environments: shifting incentives and unintended consequences of competition-based educational reforms. American Journal of Education, 111(4), 464-486.

Lubienski, C., Gulosino, C. and Weitzel, P. (2009). School choice and competitive incentives: mapping the distribution of educational opportunities across local education markets. American Journal of Education, 115(4), 601-647.

Maroy, C. and Van Zanten, A. (2009). Regulation and competition among schools in six European localities. Sociologie Du Travail, 51(S), 67-79.

Martínez, L. (2012). Apuntes sobre la territorialidad de la desigualdad: la educación pública en la zona sur de la Ciudad de Buenos Aires. Boletín de Antropología Y Educación, 3(4), 7-11.

McGinn, K.C. and Ben-Porath, S. (2014). Parental engagement through school choice: some reasons for caution. Theory and Research in Education, 12(2), 172-192.

Mezzadra, F. and Rivas, A. (2010). Aportes estatales a la educación de gestión privada en la provincia de Buenos Aires. Documentos de Trabajo CIPPEC. Buenos Aires: CIPPEC.

Montoya, S. and Frugoni, M. (2016). ¿Eficiencia o suficiencia en el sector de gestión privada? Revista Colombiana de Educación, 70, 149-174.

Moschetti, M. (2015). Private education supply in disadvantaged areas of the city of Buenos Aires and 'low-fee private schooling': comparisons, contexts, and implications. EPAA-AAPE, 23(126), 1-26.

Musa, L. (2013). Niñez, Adolescencia y Salud Mental en la Ciudad de Buenos Aires. Informe final de gestión del Ministerio Público Tutelar. Buenos Aires: Eudeba.

Nathan, J. (1996). Charter Schools: Creating Hope And Opportunity For American Education. New York: Jossey-Bass.

Patrinos, H.A., Barrera Osorio, F. and Guáqueta, J. (2009). The Role and Impact of Public-Private Partnerships in Education. Washington DC: World Bank Publications.

Rich, P.M. and Jennings, J.L. (2015). Choice, information, and constrained options: school transfers in a stratified educational system. American Sociological Review, 80(5), 1069-1098.

Robertson, S.L., Mundy, K.E., Verger, A. and Menashy, F. (2012). Public Private Partnerships in Education: New Actors and Modes o Governance in 
a Globalizing World. Cheltenham, UK and Northampton, MA, USA: Edward Elgar Publishing.

Sigal, M., Antúnez, D., Pérez Bello, J.P., Mamberti, J.M., Rosenberg, L. and Díaz, M.E. (2011). Subsidios estatales a escuelas de gestión privada en la Ciudad de Buenos Aires. Buenos Aires: ACIJ.

Srivastava, P. (2007). For philanthropy or profit? The management and operation of low-fee private schools in India. In P. Srivastava and G. Walford (eds), Private Schooling in Less Economically Developed Countries: Asian and African Perspectives (pp. 153-186). Oxford: Symposium Books.

Srivastava, P. and Hopwood, N. (2009). A practical iterative framework for qualitative data analysis. International Journal of Qualitative Methods, 8(1), 76-84.

Tiramonti, G. (2004). La trama de la desigualdad educativa: mutaciones recientes en la escuela media. Buenos Aires: Ediciones Manantial.

Van Zanten, A. (2009). Competitive arenas and schools' logics of action: a European comparison. Compare: A Journal of Comparative and International Education, 39(1), 85-98.

Vandenberghe, V. (1999). Combining market and bureaucratic control in education: an answer to market and bureaucratic failure? Comparative Education, 35(3), 271-282.

Verger, A., Bonal, X. and Zancajo, A. (2016). What are the role and impact of public-private partnerships in education? A realist evaluation of the Chilean education quasi-market. Comparative Education Review, 60(2), 1-26.

Verger, A., Fontdevila, C., Rogan, R. and Gurnet, T. (2017). Evidence-based policy or policy-based evidence? A bibliometric analysis of the education privatisation debate. International Journal of Education Development (in press).

Verger, A., Fontdevila, C. and Zancajo, A. (2016). The Privatisation of Education: A Political Economy of Global Education Reform. New York: Teachers College Press.

Verger, A. and Zancajo, A. (2015). Review of Education Policy in Developing Countries edited by Paul Glewwe. Comparative Education Review, 59(2), 366-371.

Villarroya, A. (2002). A look at school choice in Spain. Mediterranean Journal of Educational Studies, 7, 21-36.

Vior, S.E. and Rodríguez, L.R. (2012). La privatización de la educación argentina: un largo proceso de expansión y naturalización. Pro-Posições, 23(2), 91-104.

Walford, G. (2011). Low-fee private schools in England and in less economically developed countries: what can be learnt from a comparison? Compare, 41(3), 401-413.

Waslander, S., Pater, C. and Van Der Weide, M. (2010). Markets in Education. An Analytical Review of Empirical Research on Market Mechanisms in Education. Paris: OECD Directorate for Education.

West, A., Ingram, D. and Hind, A. (2006). 'Skimming the cream': admissions to charter schools in the United States and to autonomous schools in England. Educational Policy, 20(4), 615-639. 
Woods, P., Bagley, C. and Glatter, R. (1998). School Choice and Competition: Markets in the Public Interest? London: Routledge.

Zancajo, A. (2017). Educational providers in the marketplace: marketing responses in Chile. The Journal of Educational Research, ahead-of-print. 